\title{
Transformed Follicular Lymphoma to Diffuse Large B-Cell Lymphoma
}

National Cancer Institute

\section{Source}

National Cancer Institute. Transformed Follicular Lymphoma to Diffuse Large B-Cell Lymphoma. NCI Thesaurus. Code C139681.

Histologic transformation of an indolent follicular non-Hodgkin lymphoma to an aggressive diffuse large B-cell lymphoma. 